\title{
Penerapan Model Delikan dan CTL untuk Meningkatkan Prestasi Belajar Pancasila dan Pengembangan Karakter Mahasiswa PGSD FKIP Unib
}

\author{
Osa Juarsa \\ Program Magister Pendidikan Dasar Universitas Bengkulu
}

\section{Puspa Djuwita}

Program Magister Pendidikan Dasar Universitas Bengkulu

Abstract

Penelitian ini bertujuan menganalisis peningkatan prestasi belajar Pancasila serta ketertanaman karakter pada diri mahasiswa dan mendekripsikan strategi yang paling tepat dilakukan melalui pembelajaran model delikan, dan CTL. Metode pendekatan menggunakan kaji tindak latar kelas atau clasroon action reserch. Penelitian ini dilaksanakan di kelas 1A PGSD FKIP UNIB TA 2019/2020 dengan menggunakan sistem siklus. Setiap siklusnya terdiri atas beberapa tahapan yaitu: (1) Perencanaan (planning); (2) Pelaksanaan tindakan (action); (3) Pengamatan (observation); dan (4) Refleksi (reflection), Metode pengumpulan data yang digunakan adalah Observasi ,Tes Hasil Belajar, Wawancara. Metode Analisis Data dengan penilaian acuan patokan (PAP), analisa data hasil sebelum dan sesudah perlakuan/treatment digunakan statistik mean serta data yang tidak bisa dianalisa dengan rumus statistik akan dinarasikan kemudian diberi argumen. Hasil penelitian menunjukkan bahwa prestasi belajar mahasiswa dapat ditingkatkan dari rata-rata hasil belajar kelas 66,60 menjadi 83 serta terjadi ketertanaman karakter kedalam diri mahasiswa. Rata-rata skor hasil ceklis pengamatan perubahan karakter mahasiswa atas nilai-nilai yang terkandung dalam materi pembelajaran pada siklus 2 jauh lebik daripada pada siklus 1, dimana rata-rata skor pada siklus 1 sebesar 66,25 dan rata-rata skor pada siklus 2 sebesar 80,06. Peningkatan ini terjadi setelah mahasiswa diajak menggali nilai yang terkandung dalam materi yang dipelajari juga diajak untuk mamantau keterbiasaan melakukan, dan mengkaji dengan cara mengemukakan pertanyaan apa, mengapa, bagaimana, siapa, dimana dan kapan dilakukan serta kemana harus dipertanggungjawabkan serta dilakukan secara terus menerus.

Kata kunci : Delikan, CTL Karakter dan prestasi belajar

\section{Pendahuluan}

Berbagai upaya untuk merealisasikan tercapainya tujuan PGSD telah dilakukan. Salah satunya adalah peningkatan kualitas proses pembelajaran kepada mahasiswa sebagai intinya. Mereka direkayasa agar mampu memanfaatkan perkembangan potensi yang dimiliki dalam upaya meraih prestasi belajar dan peningkatan karakter 
semaksimal mungkin. Harapan tersebut tidak akan pernah tercapai jika dalam proses pembelajaran dosen tidak memperhatikan siapa peserta didik/mahasiswanya serta menggunakan model pembelajaran yang inovatif integrative.

Rerata prestasi belajar mahasiswa PGSD (khususnya mata kuliah Pancasila) masih berada pada kategori di bawah yang seharusnya mereka capai. Demikian juga halnya pada pengembangan dan penanaman karakter masih ada penyimpangan, seperti masih sering terdengar berita bahwa ada mahasiswa PGSD mabukmabukan, waktunya sholat wajib masih banyak yang tidak solat, terjadi pencurian computer miliki kampus oleh mahasiswa. Artinya secara penanaman dan pembentukan karakater calon guru SD belum sepenuhnya tercapai. Ini berarti bahwa penyelenggaraan program PGSD FKIP UNIB belum sepenuhnya mencapai harapan tujuan program PGSD yaitu melaksanakan program pendidikan yang mampu memberikan kesempatan kepada mahasiswa yang memiliki potensi kecerdasan dan bakat istimewa mampu berkembang secara maksimal sebagai calon guru SD, baik secara akademik maupun karakter. Tentunya harapan tersebut hanya akan tercapai apabila para dosen PGSD menggunakan pendekatan pembelajaran yang mampu memberikan pelayanan sesuai dengan karakteristik mahasiswa yang memiliki potensi kecerdasan dan bakat istimewa sehingga merekadapat berprestasi, apalagi apabila kita lihat bahwa pembelajaran Pancasila merupakan inti penamaman dan pembentukan karakter sebagai good citizenship. Menurut Sunaryo Kartadinata (1999) kekeliruan dalam gaya penyajian dapat menimbulkan kelambanan atau kegagalan yang dialaminya dalam belajar. Oleh karena itu seyogyanya para dosen memahami benar faktor-faktor yang dapat menimbulkan kesulitan dan kegagalan mahasiswa dalam proses belajar.

Sebagai dosen pemberi kuliah Pancasila telah melakukan berbagai upaya perbaikan pembelajaran, namun cara dan strategi yang diterapkan masih cenderung memperlakukan sama antara mahasiswa superior dengan para mahasiswa yang di bawah superior. Strategi pembelajaran yang selama ini dosen Pancasila terapkan adalah menyampaikan materi isensi dan belum banyak mengaitkan nilai dan norma yang terkandung di dalamnya, yang diikuti dengan pemecahan masalah dalam diskusi kelompok. Pemanfaatan media elektronik sperti computer-infocus telah mereka terapkan, namun pemanfaatannya masih terbatas sebagai sarana penyaji pokok-pokok esesnsi materi.

Pembelajaran Pancasila dengan menyajikan materi-materi esensi yang diikuti dengan kegiatan pemecahan masalah dalam diskusi kelompok telah dilakukan oleh dosen Pancasila Prodi PGSD. Namun sesuatu hal yang terlupakan oleh dosen tersebut bahwa diskusi kelompok yang dilakukan hanya menuntut terselesainya tugas yang diberikan kelompok, belum banyak melihat dari aspek kerjasama saling membelajarkan, semangat belajar dan lain-lain. Hal ini berakibat tidak semua mahasiswa bekerja secara efektif menyelesaikan tugas kelompok, penyelesaian tugas kelompok hanya didominasi oleh beberapa annggota kelompok yang memiliki kemampuan yang lebih tinggi (uppergroup), sementara anggota kelompok yang lain (lower group) cenderung pasif, cenderung titip nama, karena merasa pekerjaan telah diselesaikan oleh anggota kelompok yang dipercaya mamapu menyelesaikannya. Proses pembelajaran yang demikian akan mengakibatkan hasil belajar yang baik hanya akan terjadi pada upper groups (kelompok atas), sementara bagi lower group akan cenderung memiliki hasil belajar rendah. Dengan kata lain hasil belajar tidak merata secara maksimal. Selain itu pemberian materi secara esensi tanpa para mahasiswa diberikan kesempatan untuk melihat, mencerna, saling kerjasama secara disiplin dan mengalami kehidupan riil serta mencoba mengkonstruksi konsep sendiri mereka akan cenderung menghafal.Sementara materi yang lain diabaikan, apalagi apabila dilihat keternaman karakter. Suatu hal yang tidak boleh dilupakan bahwa secara umum para mahasiswa yang termasuk kategori superior adalah malas menghafal, kemalasan menghafal akan menyebakan prestasi belajar mahasiswa 
pada mata kuliah Pancasila tidak maksimal. Hal terakhir ini juga yang menjadi penyebab hasil belajar mahasiswa tidak maksimal baik prestasi akademik maupun tertanamnya karakter. Dengan kata lain strategi pembelajaran yang demikian menjadi penyebab mahasiswa superior mengalami kejenuhan serta faktor ini pula yang menyebakan para mahasiswa superior tidak menyukai Pancasila. Kegagalan mencapai prestasi maksimal akan menyebabkan terjadinya low self esteem. Low self esteem yang kurang akan membentuk self concept kurang percaya diri dan akan memepengaruhi keberhasilan dirinya dalam mengikuti pelajaran lebih lanjut (Agus Susanta dan Sri Saparahayuningsih, 2001). Sementara mahasiswa yang memiliki harga diri yang tinggi ia akan merasa percaya diri untuk mampu melakukan sesuatu atau sense of self efficacy dan ini akan mempangaruhi tingkat keberhasilan belajarnya (Bandura, 1982b).

Prestasi belajar rendah akan dapat ditingkatkan apabila proses pembelajaran mampu meningkatkan motivasi, kemauan, daya serap dan tingkat konsentrasi mahasiswa. Ini akan terjadi apabila dalam proses belajar mahasiswa memperoleh pengetahuan secara bertahap seperti halnya model struktur pengetahuan itu terbentuk yaitu mulai dari fakta, ke konsep dan akhirnya ke generalisasi (Savage and Amstrong, 1996; Numan Somantri, 2001). Dengan cara ini akan memungkinkan mahasiswa belajar dengan lebih mudah karena ia akan belajar mulai dari yang kongkret dan secara bertahap menuju ke abstrak, dari sederhana menuju ke yang kompleks. Gagne and Briggs, (1979) mengatakan bahwa kecakapan dan ketrampilan belajar akan meningkat apabila proses pembelajaran dirancang dengan memperhatikan perbedaan mahasiswa. Dengan cara ini memungkinkan dosen melakukan pembelajaran dengan pendekatan dan strategi sesuai dengan tingkat kecepatan dan gaya belajar masing-masing mahasiswa. Sri Anitah (1990) mengatakan bahwa salah satu cara yang akurat untuk meningkatakan prestasi belajar mahasiswa yang cerdas adalah dengan menggunakan pembelajaran model delikan (dengar-lihat-kerjakan). Dengan model delikan mahasiswa cerdas dapat mendengar-melihat- dan mengerjakan baik yang dimodelkan oleh dosen maupun lingkungan mahasiswa, baik berupa isi materi amupun nilai-nilai dan norma yang seharusnya dilakukan, sehingga mudah mencerna materi yang disampaikan oleh dosen karena mahasiswa ini akan mendengar langsung, melihat melalui pengalamannya sendiri, dan mengerjakan sehingga mereka aktif. Dengan pembelajaran model delikan mahasiswa cerdas akan mudah mencerna materi dan lama tersimpan dalam memori. Ellis dan Whalen (2004) mengatakan para mahasiswa cerdas akan semua aktif belajar secara bekerja sama dan interdependent untuk mencapai hasil yang maksimal apabila diterapkan pendekatan contectual teaching learning (CTL).

Dari uraian tersebut dirasa sangat urgen sekali dilakukan penelitian yang lebih mendalam dalam pemecahan persoalan belajar mahasiswa melalui pembelajaran model delikan, dan CTL secara terpadu. Penelitian ini bertujuan untuk mendekripsikan strategi yang paling tepat dilakukan serta menganalisis adanya peningkatan prestasi belajar para mahasiswa sampai taraf yang seharsunya mereka capai juga menganalisis ketertanaman nilai-nilai karakter setelah diberikan pembelajaran model delikan, dan CTL.

\section{Metode}

Metode pendekatan yang digunakan dalam penelitian ini adalah dengan menggunakan pendekatan kaji tindak latar kelas atau clasroon action reserch. Penelitian ini dilaksanakan di ruang kelas dengan menggunakan sistem siklus. Setiap siklusnya terdiri atas beberapa tahapan yaitu: (1) Perencanaan (planning); (2) Pelaksanaan tindakan (action); (3) Pengamatan (observation); dan (4) Refleksi (reflection), (Lewin dalam Arikunto 2006 : 92) 
Penelitian ini dilakukan di Kelas 1 A PGSD FKIP UNIB. Subyek penelitian dalam penelitian ini adalah para mahasiswa dan dosen Pancasila (Peneliti). Penelitian dilaksanakan 2 siklus. Masing-masing siklus dilaksnakan 2 kali pertemuan kelas (termasuk evaluasi).

\section{Teknik Pengumpulan Data}

Metode pengumpulan data yang digunakan dalam penelitian ini adalah observasi digunakan untuk mengumpulkan data tentang tampilan dosen/peneliti saat melakukan pembelajaran dengan model delikan, dan CTL serta untuk mengamati perilaku mahasiswa, tes hasil belajar digunakan untuk mengumpulkan data tentang kemampuan mahasiswa dalam menguasai pelajaran serta wawancara digunakan untuk membantu mengumpulkan data yang berkaitan dengan respon mahasiswa terhadap PBM yang ditampilkan dosen.

Analisa data tentang hasil belajar mahasiswa digunakan dengan penilaian acuan patokan (PAP), analisa data hasil sebelum dan sesudah perlakuan/treatment digunakan statistik Mean, data yang tidak bisa dianalisa dengan rumus statistik akan dinarasikan kemudian diberi argumen. Indikator keberhasilan penelitian ini yaitu 1) $80 \%$ mahasiswa berpatisipasi secara aktif dalam proses pembelajaran delikan dan CTL yang diterapkan oleh dosen. 2) Seluruh mahasiswa mengalami proses belajar mulai adanya masalah, merumuskan hipotesis, mengumpulkan fakta, menganalisa, mengkonstruksi, menyimpulkan, menilai konsep, dan generalisasi berdasarkan fakta yang diperoleh, serta mengaitkan penerapannya dalam kehidupan sehar-hari sehingga membudaya atau mengkarakter 3)75\% mahasiswa menguasai 80\% kompetensi dasar yang seharusnya dikuasai. 4) $75 \%$ mahasiswa mengalamai peruhaan perilaku sebagai hasil pengahayatan nilai-nilai yang dipelajari

\section{Hasil}

Tema utama penelitian ini adalah penanaman karakter dan peningkatan prestasi belajar Pancasila mahasiswa PGSD melalui model delikan, dan CTL. Peneliti menetapkan lokasi penelitian tindakan kelas ini dilaksanakan pada mahasiswa S1 PGSD Semester 1 TA 2019-2020 FKIP UNIB. Lokasi ini dipilih, karena struktur program mata kuliah Pancasila berada pada semseter 1 dan dana yang digunakan dalam penelitian ini adalah dana untuk peningkatan mutu pemebelajaran di lingkungan FKIP UNIB. Berdasarkan kondisi lingkungan pembelajaran mahasiswa, peneliti menyusun model pembelajaran yang diperkirakan mampu menggugah semangat pengembangan karakter dan menghasilkan pengetahuan riil yang mudah difahami serta diingat dalam bentuk pendekatan pembelajaran model delikan dan CTL. Pembelajaran ini dilakukan 2 (dua) siklus.

\section{Siklus I}

Pada siklus I, materi pembelajaran yang dipelajari adalah tentang "Demokrasi". Pada siklus I ini, peneliti bersama anggota peneliti melakukan skenario model pendekatan pembelajaran delikan, dan CTL dilakukan dengan langkah-langkah sebagi berikut:

a. Mengembangkan pemikiran dan wawasan kepada mahasiswa bahwa hasil belajar mereka akan lebih bermakna dan mencapai hasil yang maksimal apabila dalam proses belajar dilakukan dengan cara bekerja sendiri, menemukan sendiri, dan mengkonstruksi sendiri pengetahuan dan keterampilan barunya. Sementara dosen hanya berfungsi sebagai fasilitator dan motivator dalam proses belajar mahasiswa.

b. Mahasiswa mempelajari terlebih dahulu materi kajian dengan cara membaca buku sumber selajutnya dibahas bersama dosen konsep-konsep dasar/inti materi pembelajaran. 
c, Membagi mahasiswa menjadi beberapa kelompok belajar (masing-masing kelompok terdiri 4-6).

d. Membagi tugas-tugas dan permasalahan yang perlu diselesaikan dan dipecahkan dalam kelompok belajar yaitu tugas dan permasalahan yang berhubungan kompetensi dasar yang harus dikuasai oleh mahasiswa dalam mata kuliah Pancasila.

e. Mendiskusikan aturan kerja kelompok bersama mahasiswa agar proses kerja kelompok bisa berjalan secara kooperatif, adanya individual accountability, interdependence, face to face promotive interaction, dan peerdebreifing.

f. Masing-masing kelompok melakukan inkuiri. Para mahasiswa melakukan proses inquiri dengan menelaah buku teks Pancasila secara mendalam dan berdiskusi berdasarkan persoalan dan tugas yang diberikan oleh peneliti. Dalam proses inkuiri ini, peneliti memotivasi, mendampingi, dan memfasilitasi masing-masing kelompok demi lancarnya pencapaian tujuan masing-masing kelompok. Pada saat ini pula peneliti mengevaluasi kinerja proses kerja kelompok. Pada setiap tugas dan atau pemecahan permasalahan masing-masing kelompok disuruh menyusun dan menilai konsep serta generalisasi berdasarkan pada fakta-fakta yang diperoleh.

g. Masing-masing kelompok mepresentasikan dan mempertanggung-jawabkan hasil kerjanya di depan kelas.

h. Kelas (peneliti bersama semua mahasiswa) menyimpulkan hasil dari materi yang telah dipelajari.

i. Melalui diksusi, dosen bersama mahasiswa menggali dan menyepakati nilai-nilai karakter dari materi perkuliahan yang telah dipelajari untuk diimplementasikan dalam kehidupan sehari-hari.

y. Dosen dan mahasiswa membuat kesepakatan untuk melatih membiasakan diri mentaati nilai-nilai karakter yang telah digali dan disepakati bersama.

1. Masing-masing mahasiswa saling menilai dalam kehidupan sehari-hari dikampus maupun asrama tentang pengamalan nilai-nilai karakter tersebut minimal selama 1 minggu.

m. Melakukan refleksi dan atau peer debriefing di akhir pertemuan. Demi keberhasilan proses kerja kelompok selanjutnya, setiap anggota kelompok merefleksi diri untuk selanjutnya mengemukakan apa yang telah dilakukan dan belum dilakukan serta apa yang telah dan belum bisa disumbangkan pada kelompok.

n. Melakukan penilaian secara menyeluruh aspek-aspek yang seharusnya dinilai (authentic assessment) secara konsep maupun praktik. Pengamatan secara praktik nilai dilakukan berdasarkan ceklis lembar pengamatan.

Berdasarkan skenario yang disepakti bersama, pada saat peneliti melakukan proses pembelajaran, anggota peneliti yang lain melakukan pengamatan. Setelah evaluasi formatif dilaksanakan, peneliti melakukan refleksi atas kegiatan dan hasil pembelajaran yang telah dilakukan. Adapun rata-rata hasil evaluasi pembelajaran (baik hasil penilaian atas hasil kerja mahasiswa, keaktifan individu dalam diskusi kelompok, hasil kerja kelompok, maupun hasil tes) hanya mencapai rata-rata nilai 68.. Sedang perubahan nilai atau karakter dalam diri mahasiswa pada siklus 1 bila dikuantifikasikan memiliki skor rata-rata 66,25.

Berdasarkan refleksi yang dilakukan, ditemukan informasi yaitu para mahasiswa mengalami kesulitan dalam mencerna persoalan dan tugas yang diberikan oleh peneliti. Hal ini disebabkan tugas dan permasalahan yang diberikan oleh peneliti terlalu general atau kurang rinci. Peneliti belum menjelaskan tentang apa yang dimaksudkan dengan fakta, konsep generalisasi dan teori dalam materi Pancasila, akibatnya walaupun telah melakukan tugas individu dan diskusi kelompok, 
mahasiswa mengalami kesulitan dalam menyusun konsep, generalisasi dan teori. Ada satu kelompok mahasiswa walupun belum dijelaskan secara rinci tentang apa, mengapa dan bagaimana sesuatu tugas harus dilakukan, mereka mampu menyusun konsep, generalisasi dan teori. Berdasarkan wawancara kepada anggota kelompok tersebut mereka memberikan informasi bahwa ia mendapatkan bimbingan dari kakaknya. Kakaknya menasehatkan bahwa dalam mengerjakan tugas perlu difahami telebih dahulu mengapa ini dilakukan dan bagaimana ini dilakukan. Dari informasi ini kelompok tersebut mampu melakukan tugas-tugas yang diberikan dan mampu menyusun konsep, generaslisasi dan teori berdasarkan fakta-fakta yang diperoleh dari buku-buku teks yang ditugaskan untuk dibaca. Namun pada pertengahan diskusi sebagian para mahasiswa agak mengalami kesulitan dan kebingungan dalam melabeli data untuk dibentuk dalam suatu konsep, generalisasi dan teori karena para mahasiswa merasakan bahwa materi teks Pancasila yang diberikan oleh peneliti sulit difahami.

Setelah peneliti lakukan penelaahan lebih lanjut terhadap buku teks Pancasila yang diharapkan ditelaah oleh para mahasiswa ternyata memang bahwa buku teks Pancasila tersebut karena kurang disertai sketsa dan contoh-contoh dalam praktik kehidupan sehari-hari. Selain itu dalam pembelajaran, pembagian kelompok tidak heterogen berdasarkan kemampuan sehingga dalam proses diskusi kelompok terjadi timpang, ada kelompok aktif, hidup berdiskusi dan cepat menyelesaikan tugas namun ada juga kelompok yang kurang aktif dan mengalami kesulitan dalam menyelesaikan tugas. Selain itu dalam waktu 100 menit mayoritas kelompok tidak mampu menyelesaikan dan mengembangkan materi selain buku teks yang telah disediakan. Dalam proses penggalian nilai-nilai yag terkandung dalam bahan pembelajaran yang dipelajari, peneliti baru mengajak mahasiswa untuk menelaah nilai-nilai apa yang ada dalam materi yang baru saja dipelajari. Dalam hal ini peneliti belum mengajak mahasiswa untuk berfikir mengapa nilai-nilai itu ada dan mengapa perlu dilakukan, bagaimana dilakukan, siapa yang seharusnya melakukan, kapan dan dimana dilakukan serta kepada siapa hal itu dipertanggungjawabkan. Akibat dari proses ini mahasiswa baru bisa menginventarisasi nilai yang ada pada materi yang dibelajari dan belum bisa berfikir mengapa nilai dilakukan, bagaimana dilakukan, siapa yang seharusnya melakukan, kapan dan dimana dilakukan serta kemana dipertanggungjawabkan serta belum bisa menjadi kebiasaan kareana pengamatan terhadap perubahan karakater hanya dalam waktu satu minggu.

Pada siklus 1 ini peneliti menemukan sesuatu yang sangat penting untuk diperhatikan bahwa (1) pemberian tugas harus dijelakaskan secara rinci tentang apa, mengapa dan bagaimana mahasiswa harus melakukan; (2) dengan cara ini mahasiswa tidak akan mengalami kebingungan tentang apa yang akan dilakukan, mengapa dilakukan dan bagaimana melakukannya; (3) pemahaman mahasiswa tentang apa, mengapa dan bagaimana sesuatu yang harus dilakukan sangat memungkinkan mahasiswa untuk mampu menyusun konsep, generalisasi dan teori; (4) mahasiswa perlu disiapkan media pembelajaran (seperti buku yang dilengkapai sketsa dan contoh-contoh dalam kehidupan sehari-hari) dan bantuan media lainnya seperti spesimen, gambar yang memungkinkan mereka mudah memahami; (5) pembagian kelompok perlu dilakukan secara hiterogen agar mereka mampu saling membelajarkan; (6) demi efektivitas penggunaan waktu dan pengembangan serta pendalaman materi pembelajaran sebelumnya mahasiswa perlu ditugasi mencari leiteratur lain yang mampu mendukung pencapaian tujuan belajar; (7) dalam penggalian nilai mahasiswa tidak hanya diajak untuk menginventarisasi nilai tetapi harus diajak berfikir sampai ke pertanyaan apa, mengapa, bagaimana, siapa yang melakukan, kapan dan dimana nilai dilakukan, dan diperatnggungjabwakan. (8) Agar nilai-nilai yang telah digali menjadi terinternalisasi ke dalam diri mahasiswa, mereka perlu dibiasakan untuk menerapkannya dalam kehidupan sehari-hari. 
Berdasarkan hasil refleksi yang telah dilakukan, peneliti menyusun skenario tindakan proses pembelajaran uktuk sikulus II dengan materi pembelajaran tentang "Pembukaan Undang Undang Dasar 1945."

\section{Siklus II}

Berdasarkan hasil pengamatan, penilaian dan refleksi pada siklus I, penelitian dilanjutkan pada siklus II dengan skenario tindakan proses pembelajaran sebagai berikut.

a) Mengembangkan pemikiran dan wawasan kepada mahasiswa kembali bahwa hasil belajar mereka akan lebih bermakna dan mencapai hasil yang maksimal apabila dalam proses belajar dilakukan dengan cara bekerja sendiri, menemukan sendiri, dan mengkonstruksi sendiri pengetahuan dan keterampilan barunya. Sementara dosen hanya berfungsi sebagai fasilitator dan motivator dalam proses belajar mahasiswa.

b) Mahasiswa membaca buku sumber tentang makna pembukaan UUD 1945 bagi bangsa Indonesia, selanjutnya dibahas bersama dosen tentang konsep-konsep dasar/inti materi pembelajaran disertai sketsa dan contoh-contoh dalam kehidipan sehari-hari.

c) Membagi mahasiswa menjadi beberapa kelompok belajar (masing-masing kelompok terdiri 4-7mahasiswa) secara hiterogen yaitu dengan cara (a) menentukan berapa anggota kelompok dalam belajar mahasiswa, pada siklus 2 ini mahasiswa dibagi menjadi 5 kelompok dengan masing-masing kelompok beranggotakan 7 mahasiswa; (b) menyuruh mahasiswa untuk berhitung 1sampai dengan 5 . Kemudian mahasiswa yang beranomor 1 berkumpul manjdi kelompok 1 dan mahasiswa bernomor 2 berkumpul menjadi anggota kelompok dua dan seterusnya.

d) Membagi tugas-tugas dan permasalahan yang perlu diselesaikan dan dipecahkan dalam kelompok belajar yaitu tugas dan permasalahan yang berhubungan kompetensi dasar yang harus dikuasai oleh mahasiswa dalam mata kuliah Pancasila.

e) Menjelaskan secara rinci tentang tugas-tugas dan permasalahan yang diharapkan diselesaikan dan atau dipecahkan oleh para mahasiswa tentang apa, mengapa dan bagaimana permasalahan seharusnya dilakukan.

f) Mendiskusikan aturan kerja kelompok bersama mahasiswa agar proses kerja kelompok bisa berjalan secara kooperatif, adanya individual accountability, interdependence, face to face promotive interaction, dan peerdebreifing.

g) Agar harapan point $f$ terjadi, sebelum kelompok melakukan kerja kelompok dibertahukan bahwa kegagalan seorang anggota kelompok mepertanggungjawabkan hasil kerja kelompok mengurangi nilai kelompok dan keberhasilan anggota kelompok dalam mempertanggungjawkan hasil kerja kelompok akan menambah nilai kelompok.

h) Masing-masing kelompok melakukan inkuiri. Para mahasiswa melakukan proses inquiri dengan menelaah buku teks Pancasila dan berdiskusi berdasarkan persoalan dan tugas yang diiberikan oleh peneliti. Dalam proses inkuiri ini, peneliti memotivasi, mendampingi, dan memfasilitasi masing-masing kelompok demi lancarnya pencapaian tujuan masing-masing kelompok. Pada saat ini pula peneliti mengevaluasi kinerja proses kerja kelompok. Pada setiap tugas dan atau pemecahan permasalahan masing-masing kelompok disuruh menyusun dan menilai konsep serta generalisasi berdasarkan pada fakta-fakta yang diperoleh.

i) Masing-masing kelompok mepresentasikan dan mempertanggungjawabkan hasil kerjanya di depan kelas. 
j) Kelas (peneliti bersama semua mahasiswa) menyimpulkan hasil kerja masingmasing kelompok.

k) Melalui diksusi, peneliti bersama mahasiswa menggali dan menyepakati nilainilai karakter dari materi perkuliahan yang telah dipelajari untuk dimplementasikan dalam kehidupan sehari-hari, serta mengajak berfikir mahasiswa untuk mempertanyakan pertanyaan apa, mengapa, bagaimana, siapa yang melakukan, kapan dan dimana nilai itu dilakukan serta dipertanggungjawabkan.

l) Dosen dan mahasiswa membuat kesepakatan untuk melatih membiasakan diri mentaati nilai-nilai karakter yang telah digali dan disepakati bersama.

m) Masing-masing mahasiswa saling menilai dalam kehidupan sehari-hari dikampus maupun asrama tentang pengamalan dari nilai-nilai karakter tersebut selama 2 minggu.

n) Pada akhir pertemuan sikulus kedua ini peneliti menyuruh masing-masing kelompok melakukan refleksi dan atau peer debriefing, yakni demi keberhasilan proses kerja kelompok selanjutnya setiap anggota kelompok (a) merefleksi diri tentang apa-apa yang telah dilakukan, (b) mengemukakan apa yang telah dan apa yang belum bisa disumbangkan pada kelompok.

o) Melakukan penilaian secara menyeluruh aspek-aspek yang seharusnya dinilai (authentic assessment).

Berdasarkan skenario yang dispakati, ketika seorang anggota peneliti melaksanakan pembelajaran, sementara peneliti melakukan pengamatan. Selanjutnya ketua dan anggota peneliti melakukan refleksi. Berdasarkan refleksi yang dilakukan bersama, diketahui bahwa dalam proses diskusi para mahasiswa nampak serius dan aktif, suasana diskusi hidup, karena setiap mahasiswa menmguasai apa yang harus dilakukan, mengapa itu tugas dan permasalahan itu dilakukan dan bagaiaman tugas dan permasalahan dilakukan.

Berdasarkan refleksi dan evaluasi yang dilakukan bersama, ditemukan informasi bahwa ketua dan anggota peneliti sadar tentang pentingnya (a) buku teks Pancasila yang dilengkapi sketsa dan contoh-contoh yang mampu membimbing mahasiswa untuk berfikir secara logis yang dimulai dari pemahaman tentang materi Pancasila tentang apa dan apa yang dipelajari serta apa faktanya, mengapa fakta-fakta itu diperlukan sementara yang lain tidak; (b) dalam pembelajaran mata kuliah Pancasila para mahasiswa PGSD secara efektif dan efisien perlu didasarkan pada pola fakir apa, mengapa, bagaimana, dimana, kapan peristiwa Pembukaan UUD ' 45 dan siapa pelaku penyusunnya. Dengan mendasarkan pada hal-hal tersebut proses belajar para mahasiswa dalam diskusi lebih nampak hidup, karena setiap mahasiswa menguasai persoalan sejarah "pembukaan UUD "45" dalam pola fakir apa, mengapa, bagaimana, dimana, kapan peristiwa sejarah "pembukaan UUD ' 45 ” dan siapa pelaku sejarah "pembukaan UUD "45". Partispasi masing-masing anggota kelompok dalam diskusi juga cukup tinggi, mahasiswa lebih mudah membentuk konsep dan generalisasi, diskusi jauh lebih tertib, menarik dan mahasiswa nampak aktif, bersemangat dan percaya diri, kemampuan kognitif mereka bukan hanya sampai pada taraf aplikasi tetapi mampu menganalisa, mensitesa dan mengevalusi data, kosnep dan generalisasi. Mahasiswa juga mampu menggali nilai sampai pada taraf apa, mengapa, bagaimana, kapan dan dimana nilai itu dilakukan, kepada siapa dipertangungjawabkan dan menginternalisasikan serta mengaplikasnya dalam kehidupan sehari-hari. Selain itu hasil evaluasipun meningkat dibanding hasil evaluasi pada siklus I. Selain itu para mahasiswa akhirnya mampu menemukan konsep untuk melabeli data-data lapangan yang telah mereka kumpulkan dan klasifikasikan. Pada siklus II, rata-rata prestasi belajar para mahasiswa (baik hasil penilaian atas hasil kerja dalam telaah teks untuk memeproleh fakta, merumuskan konsep, melakukan generalisasi dan teori, keaktifan individu dalam diskusi 
kelompok, hasil kerja kelompok, maupun hasil tes) lebih baik dari pada pada siklus II yang hanya mencapai rata-rata nilai 83. Demikian juga rata-rata skor hasil ceklis pengamatan perubahan karakter mahasiswa atas nilai-nilai yang terkandung dalam materi pembelajaran pada siklus 2 jauh lebik daripada pada siklus 1 , dimana ratarata skor pada siklus 1 sebesar 66,25 dan rata-rata skor pada siklus 2 sebesar 80,06

\section{Pembahasan}

Berdasarkan data dokumentasi, prestasi belajar Pancasila yang dicapai mahasiswa sebelum dilakukan PTK yang hanya 60-74. Ini berarti bahwa mayoritas mahasiswa sebelum dilakukan PTK dengan pembelajaran model delikan, dan CTL tergolong rendah. Setelah dilakukan penelitian tindakan kelas terjadi suatu perubahan prestasi belajar yaitu 31 orang mahasiswa mampu mencapai pretasi belajar sesuai dengan tingkatan potensi akademik yang mereka miliki, sementara 4 orang mahasiswa belum mencapai pada prestasi belajar yang seharusnya dimiliki. Hal ini menunjukan bahwa pelaksanaan PTK dengan dengan pembelajaran model delikan, dan CTL mampu mengubah mahasiswa yang tadinya hanya 9 orang mahasiswa yang berprestasi menjadi 31 orang mahasiswa

Hal tersebut memberikan pemahaman kepada kita bahwa potensi mereka masih bisa diberdayakan untuk memeproleh prestasi belajar sampai batas maksimal yang seharusnya mereka capai bila tersediakan kondisi lingkungan belajar yang kondusif, baik lingkungan keluarga, khususnya dari aspek perhatian orang tua, maupun lingkungan kampus yang berupa proses pembelajaran dan motivasi yang kondusif bagi proses belajarnya (Gagne, 1985). Temuan ini sejalan dengan pendapat Kartadinata (1999) yang mengatakan bahwa hasil yang dicapai mahasiswa hendaknya dapat mencerminkan tingkat kemampuan yang dimilikinya. Mahasiswa yang kemampuan dasarnya tinggi akan mencapai hasil belajar yang tinggi pula. Bilamana seseorang mahasiswa mencapai hasil belajar yang lebih rendah dari tingkat kecerdasannya yang dimilikinya, maka mahasiswa yang bersangkutan digolongkan sebagai mahasiswa yang mengalami masalah yaitu prestasinya lebih rendah dari apa yang diperkirakan berdasarkan hasil tes kemampuan belajar

Berdasarkan data yang diperoleh, kurangnya perhatian, pendidikan dan bimbingan orangtua, pemaksaan pemilihan program studi yang diinginkan serta kesalahfahaman terhadap pemahaman hakekat mahasiswa mejadi penyebab terjadinya hasil belajar rendah. Kurangnya perhatian orang tua menyebabkan hidupnya terasa hampa, tak bergairah, terasa tak ada tempat mencurahkan keluh kesahnya, bingung dan tak memiliki pegangan. Pemaksaan pemilihan program studi oleh orang tua terhadap anaknya akan menyebakan mereka menja kurang minat, kurang bertanggungjawab atas tugasnya sebagai mahasiswa serta malas belajar. Kondisi ini merupakan gambaran orang yang mengalami masalah. Orang yang bermasalah mengalami gannguan emosional, ia tidak memiliki konsentrasi dan semanagt belajar. Akibatnya prestasinya rendah. Kurangnya pendidikan dan bimbingan orang tua dalam menjalani hidup meyebabkan anak tidak memahami nilai dan norma dalam hidup di masyarakat, tidak memahami apa yang perlu dilakukan dalam hidup ini dan bagaimana cara melakukannya (Koentjaraningrat, 1987). Ia juga tidak memiliki petunjuk dan pegangan hidup apa seharusnya ia lakukan demi kehidupannya mendatang di masyarakat. Dengan kata lain, ia hidup menurut maunya sendiri tanpa arah, termasuk proses belajarnya. Ini semua menyebabkan prestasi belajar mereka menjadi rendah. Temuan ini sejalan dengan pendapat Kartadinata (1999) yang mengatakan bahwa faktor ekteranal yang berasal dari kampus (sifaf kurikulum yang kurang fleksibel, terlalu berat beban belajar murid dan atau beban mengajar dosen, metode mengajar yang kurang memadai, kurangnya alat dan sumber belajar) dan berasal dari keluarga (antara lain keluarga tidak utuh dan kurang harmonis, sikap orang tua yang tidak memperhatikan pendidikan anaknya) sangat memepengruhi prestasi belajar anak.Temuan ini juga 
didukung pendapat Cecci (dalam Ahmad Wahab, 1999) yang menegaskan bahwa kampus dapat berpengaruh positif terhadap tingkat keberhasilan belajar. Faktorfaktor ini semua akan terminimalkan kalau kondisi lingkungan strategi proses pembelajarn yang diterima kondusif, dalam arti proses pembelajaran yang diterima menarik, tidak membosankan dan peserta didik aktif terlibat dalam proses belajar. Peserta didik tidak hanya mendengar informasi, tetapi ia aktif terlibat melihat, mencari dan menemukan informasi. Selain itu ia juga terlibat secara dalam menyusun informasi menjadi konsep, meningkat ke generalisasi dan teori. Proses ini merupakan proses pendekatan pembelajaran delikan (dengar, lihat dan melakukan) (Sri Anitah, 1990).

Melalui pendekatan delikan, CTL dalam pembelajaran prestasi belajar mahasiswa dapat ditingkatkan dari rata-rata hasil belajar kelas 66,60 menjadi 83. Ini berarti bahwa para dosen tidak boleh puas dengan prestasi belajar para mahasiswa yang dicapai selama ini yakni rata-rata prestasi belajar mereka hanya mencapai 66,60. Seorang dosen bisa merekayasa proses pembelajaran atau menciptakan kondisi belajar yang mereka lakukan sedimikian rupa untuk meningkatkan kualitas dan kuantitas hasil pembelajaran yang dilakukan. Prestasi belajar mahasiswa akan meningkat apabila dosen mampu menciptakan kondisi atau lingkungan belajar atau proses pembelajara yang kondusif (Gagne, 1985). Proses pembelajaran dikatakan kondusif apabila proses pembelajaran yang diterima mahasiswa itu menarik, tidak membosankan dan peserta didik aktif terlibat dalam proses belajar. Peserta didik tidak hanya mendengar informasi, tetapi ia aktif terlibat melihat, mencari dan menemukan informasi. Selain itu ia juga terlibat secara dalam menyusun informasi menjadi konsep, meningkat ke generalisasi dan teori. Pembelajaran yang demikian mampu menumbuhkan semangat mahasiswa untuk belajar karena mereka secara bersama-sama tidak hanya mendengar informasi tetapi ia secara aktif melihat dan berbuat langsung atas fakta yang mereka pelajari, memproses sendiri fakta menjadi konsep, generalisasi dan teori. Dengan kata lain proses pembelajaran ini tidak hanya mengaktifkan sebagian diri mahasiswa yang belajar tetapi mereka belajar secara total atas dirinya yang dilakukan sendiri. Proses pembelajaran ini didukung oleh teori gestalt yang menyatakan bahwa proses belajar yang dilakukan secara total oleh yang belajar akan meningkatkan pemahaman secara utuh. Hal ini disebabkan karena seluruh indra mahasiswa sebagai pintu gerbang masuknya dan terbentuknya pengetahuan dalam diri mahasiswa bekerja belajar. Selain itu melalui pendekatan pembelajaran ini mahasiswa mengalami proses belajar dari yang kongkret menuju ke yang abstrak, dari sederhana menuju ke yang kompleks, dan dari yang mudah menuju ke yang sulit. Dengan proses penanaman nilai sampai pada pertanyaan apa, mengapa, bagaimana, siapa, dimana dan kapan dilakukan serta kemana harus dipertanggungjawabkan dan dilakukan secara terus menerus, para mahasiswa merasa mampu mengahayati, bahkan berupaya mempertahankan atau mebiasakan diri melakukan dan mempertang-gungjawabkan nilai-nilai yang dipelajari. Hal ini sejalan pendapat White (2010: 87) nyatakan bahwa... routines shape habits, which in turn establish attitudes. Dengan model delikan, dan CTL mahasiswa tidak hanya memperoleh teori tetapi memiliki kemampuan memproses informasi, menginternalisasi nilai dan sikap, serta menjadi sadar, mau, mampu dan trampil beraprtisipasi sosial yang bisa dipertanggungjawabkan terhadap dirinya sendiri, sosial dan lingkungannya dan tuhan sebagai penciptanya.

Suatu hal yang perlu diperhatikan dari temuan penelitian ini adalah walaupun dengan diterapkan pendekatan pembelajaran delikan, CTL mampu meningkatkan prestasi belajar dalam mata kuliah Pancasila para mahasiswa program PGSD FKIP Unib dari nilai-rata kelas 66,60 menjadi 83 namun belum semua mahasiswa mampu meningkatkan hasil belajar mencapai hasil belajar secara maksimal. Hal ini disebabkan oleh factor-faktor berikut: kekurangpedulian dan kekurangpemahaman tentang hakekat mahasiswa serta kekurangpengetahuan orang tua dan dosen tentang bagaimana membimbing, menyikapi dan membelajarkan mahasiswa itu 
sendiri. Perbaikan proses pembelajaran oleh dosen telah dilakukan, namun kalau kepedulian, pemahaman, dorongan dan dukungan orang tua serta pemahaman dosen tentang bagaimana menyikapi dan membimbing mereka belum dilakukan sebagaimana seharusnya maka suatu hal yang wajar kalau para mahasiswa program PGSD belum mencapai hasil secara maksimal. Demikian juga dengan ketertanaman nilai kedalam diri mahasiswa akan terjadi apabila mereka tidak hanya diajak menggali nilai yang tergandung dalam materi yang dipelajari tetapi juga diajak untuk mamantau keterbiasaan melakukan, dan mengkaji dengan cara mengemukakan pertanyaan apa, mengapa, bagaimana, siapa, dimana dan kapan dilakukan serta kemana harus dipertanggungjawabkan dan dilakukan secara terus menerus.

\section{Kesimpulan}

1) Strategi menanamkan karakter dan meningkatkan prestasi belajar mahasiswa sampai taraf yang seharusnya mereka capai melalui pembelajaran model delikan, dan CTL dilakukan melalui langkah-langkah sebagai berikut:

a. Mahasiswa mempelajari materi ajar dengan cara membaca pada buku sumber selanjutnya dibahas bersama dosen serta diberikan penjelasan inti-inti materi pembelajaran secara umum.

b. Para mahasiswa disuruh mencari, melihat, memilih dan mengumpulkan fakta-fakta atau data-data dalam dunia nyata.

c. Berdasarkan fakta-fakta atau data yang mereka peroleh, para mahasiswa diajak dan dibimbing berdiskusi untuk menyusun konsep, generalisasi dan teori

d. Bersama dosen para mahasiswa menggali nilai-nilai yang ada pada materi pembelajaran yang dipelajari.

e. Mengajak dan memantau mahasiswa untuk mengaplikasikan nilai-nilai yang dipelajari dalam kehidupan sehari-hari sehingga menjadi aktivitas rutine dan kebiasaan hidupnya

f. Bersama dosen para mahasiswa menyusun simpulan.

g. Bersama dosen mahasiswa diajak melakukan refleksi atas proses belajar yang mereka lakukan.

2.) Melalui pendekatan model delikan, CTL dalam pembelajaran, dapat meningkatkan prestasi belajar mahasiswa dari rata-rata hasil belajar kelas 66,60 menjadi 83.

3.) Terjadi ketertanaman karakter setelah diberikan pembelajaran model delikan, dan CTL kedalam diri mahasiswa. Rata-rata skor hasil ceklis pengamatan perubahan karakter mahasiswa atas nilai-nilai yang terkandung dalam materi pembelajaran pada siklus 2 jauh lebik daripada pada siklus 1 , dimana rata-rata skor pada siklus 1 sebesar 66,25 dan rata-rata skor pada siklus 2 sebesar 80,06.

\section{Saran}

1) Untuk meningkatkan prestasi belajar para mahasiswa para dosen hendaknya menerapkan pendekatan pembelajaran delikan, struktur pengetahuan dan CTL secara terintegrasi.

2) Dalam penanaman karakter, mahasiswa perlu diajak secara bersama menggali dan memantau penerapan nilai-nilai yang dipelajari dalam kehidupan sehari-hari sehingga menjadi aktivitas rutine dan kebiasaan hidupnya. 


\section{Referensi}

Bandura, A., 1982b. Self-efficay mecahanism of agenscy. American Pschologist, 37, 122-147.

Coopersmith, S dan Ronald Feldman, 1983, Fostering a Positive Self-Concept and High Self-Esteem in The Clasroom, New York: Harper and Row Publishers.

Dharma Kesuma, dkk., 2011. Pendidikan Karakter: Kajian Teori dan Praktik di Kampus, Bandung: Remaja Rosdakarya.

Gagne, R.M., 1985. The Condition of Learning , New York:

Gagne, R.M. and Briggs, L.J., 1979. Principles of Instructional Design, new York: Holt, Rinerhart, and Winston.

Mc. Taggart R., 1993, Action Research a Shot Modern History, Victoria : Deakin University Press

Muhamad Numan Somantri, 2001. Menggagas Pembaharuan Pendidikan Pancasila, Bandung: Rosda Karya.

Nana Sudjana \& Daeng Arifin, 1988, Cara Belajar Mahasiswa Aktif dalam Proses Belajar Mengajar, Bandung: Sinar Baru

Nur'ani, 1997, Intervensi Dini Bagi Anak Bermasalah, Jakarta, PT Rineka Cipta.

Oja S.N. \& Smulyan L., 1989, Collaborative Action Research: a Developmental Approach, London: The Falmer Press

Robert D. Carpenter MD, 1991, Cerdas : Cara Mengatasi Problema Belajar, Semarang: Dahara Prize

Rochmat Wahab dan Solehuddin, 1999, Perkembangan dan Belajar Peserta Didik, Jakarta : Departemen pendidikan dan Kebudayaan Direktorat Jendral Pendidikan Tinggi Proyek Pendidikan Dosen Kampus Dasar

Savage, Tom V. And Amstrong, David G, 1996. Effective Elementary Social Studies, New Jersey : Prentice Hall

Sri Anitah \& Noorhadi, 1990, Strategi Belajar Mengajar, Jakarta: Penerbit Karunia Jakarta Universitas Terbuka.

Sunaryo Karta Dinata dkk, 1999, Bimbingan di Kampus Dasar, Jakarta : Departemen pendidikan dan Kebudayaan Direktorat Jendral Pendidikan Tinggi Proyek Pendidikan Dosen Kampus Dasar

Tanck, Marlin L, 1969. Teaching Concepts, Generalizations, and Construct in Social Sudies Curriculum development: Prospect and Problems by Dorothy McClure Fraser, NCSS Wasshington. 